\title{
Accounting: the teaching, the practice and what is missing
}

\author{
Shanmugavel Rajeevan \\ Department of Accounting, University of Sri Jayewardenepura, Nugegoda, \\ Sri Lanka and Solid Analytics Lanka PVT LTD, Colombo, Sri Lanka
}

\begin{abstract}
Purpose - This paper aims to identify the knowledge and practice gap in accounting education and propose an alternative teaching method to align accounting education to meet the needs of the practical world.

Design/methodology/approach - A total of 500 questionnaires were circulated among four stakeholders (academics, accounting students, accountants in business and accountants in practice) and received an overall usable response rate of $27 \%$.
\end{abstract}

Findings - It was found that to reflect the current accounting practices, accounting students should be exposed to accounting specific experiential learning and industry specific training at an early stage of their academic education. Universities and professional institutes can work together to develop a curriculum to create an elite league of accounting professionals.

Practical implications - The insights of this study would provide guidance to educators on how to develop an advance experiential learning structure for students that reflects the current accounting practices and technologies involved.

Originality/value - This study contributes to the existing literature by means of providing an alternative teaching method for undergraduate accounting degree program.

Keywords Accountants, Accounting education, Professional accounting institutes, Sri Lanka

Paper type Research paper

\section{Introduction}

Students are exposed to technical study materials in a vocational based study environment that is distance from the real world (The Pathways Commission, 2015). Many researchers found that there is a gap between practice and theory in accounting education and it is not a recent phenomenon and the gap is widening. New materials should help accounting students to understand the basic book-keeping elements so that it will act as a foundation while conveying more strategic and dynamic aspects of accounting (Pathways Commission, 2012). Failure to introduce broader concepts of accounting subjects at an early stage can lead students to maintain status quo (Ferguson et al., 2010). Making students to be critical thinkers and problem solvers is the utmost aim of business education. Formulating a numerical view of the world that would reduce complex issues to simple understandable statements (Hemp, 2019). Traditional accounting education often emphasises on job completion, memorization and straight-forward answers that are descriptive nature of learning (Turner and Baskerville, 2013). Current dynamic business environment requires

(C) Shanmugavel Rajeevan. Published in Vilakshan - XIMB Journal of Management. Published by Emerald Publishing Limited. This article is published under the Creative Commons Attribution (CC BY 4.0) licence. Anyone may reproduce, distribute, translate and create derivative works of this article (for both commercial and non-commercial purposes), subject to full attribution to the original publication and authors. The full terms of this licence maybe seen at http://creativecommons.org/licences/by/4.0/legalcode
Received 11 June 2020 Revised 5 August 2020 8 September 2020 Accepted 9 September 2020 
$\mathrm{XJM}$

$17,1 / 2$

deep learning where students should be able to conceptualise new ideas and strategies by using the existing knowledge. Solely pursuing theory-based accounting education can produce students without social representativeness of accounting practice (Dellaportas, 2015), such deep learning is an aspect of experiential learning, which is engrained in the learning theory models developed by Lewis, Dewey and Piget (Kolb and Kolb, 2005). Continuing traditional teaching methods in dynamic business environment can produce bean counters, whereas the current business environment requires strategic business partners and critical thinkers. Several accounting literature indicate that accounting curriculum in the USA dating back to 1986 is construed as task oriented and a predictable activity (Mathews, 2001; Pathways Commission, 2012). The accounting profession expects accounting graduates to possess critical thinking, in addition to technical knowledge (Wells, 2018). Several studies have proposed different methods of incorporating experiential learning into accounting curriculum (Cowan, 1985; Kolb, 1984; Kolb, 2015; McCarthy, 2010). In general, there is a lack of recognition and collaboration between universities and professional accounting institutions in Sri Lanka, compared to the graduate accounting profession in countries such as the USA, Australia, New Zealand and Singapore (Senaratne and Cooray, 2012). However, this study proposes an alternative accounting study structure where academic and professional institutes can work together to incorporate experiential learning. An education model that integrates experiential component would be favourable to the students, as it will provide an opportunity for students to participate in new experiences, integrate observations into logical theories and use such theories to make decisions and solve problems (Kolb, 2015; McCarthy, 2010). Kolb's experiential learning model has led to increased problem-solving ability compared to traditional accounting teaching strategies. The proposed study model in this study elaborates how to incorporate practical training and advanced soft skills at an early academic stage. The proposed model would act as a guide to regulators and practitioners to develop and implement more practical accounting education compared to traditional classroom teaching.

\section{Review of literature}

\subsection{Background}

Historically accounting is primarily is focussed on summarising, analysing and interpreting the results of the financial information (PwC, 2019). Palm and Bisman (2010) provided evidence that accounting courses designed for non-accounting students also suggested that these courses are routine and does not encourage critical thinking. However, Saudagaran (1996) proposed an alternative course design where most programmes have two introductory courses, where one focusses on financial accounting while the other module focusses on management accounting. The aim of this study programme is to provide historical score-keeping attributes from a financial accounting perspective, whereas management accounting course provides an opportunity to learn about cost behaviour. This programme structure has created an illusion that these two disciplines are unrelated.

The operations of the accounting study programme can be explained Romney and Steinbart's model. A system is defined as a model where two or more interconnected components interact to achieve a common goal (Romney and Steinbart, 2018). This is depicted in Figure 1.

It is argued that accounting programmes should be more outcome driven rather than process driven. Process-driven focus is a major contributor to student's score-keeping and task-oriented perceptions of accounting.

It is important to incorporate experiential learning techniques compared to classroom teaching methods, as experiential learning encourages critical thinking that leads to 
problem articulation, research, analysis and decision-making. This will in turn produce outcome-driven accounting graduates.

In New Zealand, universities called for change in the full introductory course, where the full year course was replaced with two shorter half year courses. The first half of these courses focussed on an introduction to accounting from a user perspective. This change benefited for students who do not want major in accounting. The second half of the course in accounting is taught from a preparer perspective for students who want major in accounting (Wells, 2018).

\subsection{Knowledge progression model development}

Handbook of International Education Pronouncements (2017) was developed with the guidance of International Accounting Education Standards Board and published by the International Federation of Accountants (IFAC) and states the entry methods to professional accounting education programs and the initial professional development (IPD) of an aspiring professional accountant. Figure 2 depicts the three levels (foundation, intermediate and advanced) of proficiency described by the International Education Standard (IES) 2, 3 and 4 as presented in Figure 2. The proficiency levels are incorporated in the proposed accounting degree program.

In order for accountants to evolve from financial recorders to strategic business partners, it is necessary for their knowledge and thinking to be evolved as depicted in Figure 3.

2.2.1 Theoretical thinking. This is the initial stage of the student's knowledge (theoretical accounting foundation) and thinking progression. This accounts to knowledge gained from accounting academic programmes.

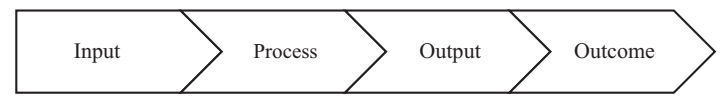

Source: Author constructed (Adopted from Romney and Steinbart's, 2018 Study)

Figure 1.

System

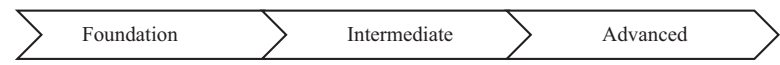

Source: The Handbook of International Education

Pronouncements (2017)
Figure 2. Proficiency levels
Accounting

\begin{tabular}{|c|c|c|c|}
\hline \multicolumn{4}{|c|}{ Knowledge and Thinking Progression } \\
\hline $\begin{array}{c}\text { Theoretical } \\
\text { Thinking }\end{array}$ & $\begin{array}{l}\text { Practical } \\
\text { Thinking }\end{array}$ & $\begin{array}{l}\text { Adaptive } \\
\text { Thinking }\end{array}$ & $\begin{array}{c}\text { Conceptual } \\
\text { Thinking }\end{array}$ \\
\hline & \multicolumn{1}{c}{$\begin{array}{c}\text { Knowledge obtained } \\
\text { from Academic } \\
\text { institutions }\end{array}$} \\
\hline
\end{tabular}

Source: Author constructed
Figure 3.

Knowledge and thinking progression gaps 
$\mathrm{XJM}$

$17,1 / 2$

18

2.2.2 Practical thinking. This is the second stage where graduate students are expected to put their theoretical knowledge to practical work-related situations.

2.2.3 Adaptive thinking. This is the third stage of knowledge progression of graduate students. In this stage the students are expected to modify or change the theoretical knowledge to suit the changing business environment requirements. Graduate students are expected to acquire new or required additional skills and techniques necessary to cater the business needs.

2.2.4 Conceptual thinking. This is the final stage of knowledge progression of graduate students where students are expected develop new knowledge, strategies, ideas or theories and institutionalise such knowledge. This is what is expected from senior professionals in the respective fields.

There is an ongoing debate that academic accounting programmes are well equipped to provide sufficient theoretical background (Theoretical Thinking 1), as presented in Figure 3; however, these study programmes do not meet the requirements or skills of a professional accountant as prescribed by the professional accounting member bodies of IFAC (Handbook of International Education Pronouncements, 2017). The list of skills aspiring professional accountants need to develop and demonstrate by the end of the IPD is presented in Appendix.

\subsection{Accountant's changing role and the need for change in accounting study curriculum}

The academic accounting curricula are constructed by scholars of the respective areas. Likierman (2004) stated that academics tend to work in isolation in terms of practical aspect of the subject and do not address the issues and challenges faced by the practitioners. Even prior studies have indicated that the graduates are not equipped with the necessary skills to satisfy the needs of the business world (Kavanagh and Drennan, 2008; Jackling and De Lange, 2009; Webb and Chaffer, 2016). Webb and Chaffer (2016) stated that higher education is not evolving at the pace that is demanded by the dynamic business world. The current academic system is a useful mechanism for students to think and know about things; however, it fails to teach how to do things (Albrecht and Sack, 2000; Craig and Amernic, 2002). The new generations of students have access to advanced technology and less patient with traditional accounting teaching methods, as they have not evolved with the time (Pathways Commission, 2012).

As it is important to restructure accounting programmes in developing countries and to produce world class strategic professional accountants, as organisations in developed nations outsource professional accounting services to developing nations (Tucker and Schltegger, 2016). Therefore, it is important to restructure academic accounting structure to produce strategic professional accountants who would be in par with the skill requirements prescribed by IES, as there is a growing global demand for competent accounting professionals. In light of the above literature review, the following hypothesis is developed:

H1. It is necessary to revise and restructure the existing state accounting degree program.

\subsection{Study framework}

The existing structure of the accounting degree program is extensively involved in classroom teaching. This structure does not facilitate students to become strategic business partners and critical thinkers. Therefore, this study proposes an alternative program 
structure for students who focusses more on experiential learning and practical experience with classroom learning.

Traditional education is teacher centred, relying on information from experts in textbooks or lectures and the evaluation is based on standardize scoring. This model allows instructor to completely control the learning environment. The proposed study framework in this study encourages to incorporate practical work experience and skill development courses at an early stage of the academic life.

The proposed state accounting undergraduate accounting degree program structure is presented in Table 1.

Experiential teaching includes methods such as equipment stimulators, role playing, sensitivity training and case study methods. The aim of experiential learning is to enhance "learning by doing" and the training involves a two way interaction unlike the informational training methods (MSG Management Study Guide, 2020).

The proposed state accounting undergraduate accounting degree program structure are presented in Table 1, which focus more on practical training requirements and skill development courses. Online internship monitoring system and bi-annual face to face interview sessions should be developed to assess whether students are complying and receiving the required internship training. Lecturing sessions after Year 1 should be more assignment based where emphasis should be on self-research and self-study. The aim of this programme structure is to increase experiential learning and increase critical thinking of the students. Instructors should adopt experiential instructions to the entire course or a segment of a course.

\begin{tabular}{llll}
\hline Year 1 & Year 2 & Year 3 & Year 4 \\
\hline $\begin{array}{l}\text { Foundation } \\
\text { Compulsory }\end{array}$ & Intermediate & Advanced & \\
full-time lectures within & Compulsory internship & Compulsory internship & Compulsory internship \\
the university. & training (Year 1 training) & training (Year 2 training) & training (Year 3 training) \\
& and & and & and \\
& After work lecturing & After work lecturing & After work lecturing \\
& sessions (Experiential & sessions (Experiential & sessions (Experiential \\
& Learning methods) & Learning methods) & Learning methods) \\
& And & And & And \\
& Skill Development & Skill Development & Accounting Research/ \\
& Courses - 1 & Courses - 2 & Dissertation
\end{tabular}

Notes: Other implementation notes in class learning should be combined with experiential learning to enhance the intellectual, technical and functional skills. Introduction of internship programs at an early stage is to develop and train academic students to be more aware and in line with the practical working requirements of the business world. This would provide students to achieve learning outcomes relating to other skills. Implement online internship monitoring system to track the progress of the students. Where students are required to submit their work completion progress on a monthly basis or a quarterly basis and this should be approved the student's immediate supervisor and senior lecturer of the accounting department. Conduct bi-annual face to face interview with the students to ensure students are making progress in the relevant area of the internship. Critical cross questioning should be carried out to ensure students are gaining the relevant practical experience and to ensure they have achieved the relevant learning objectives. Skill development courses should be developed to encourage interpersonal skills, communication skills, organizational skills and management skills

Source: Author constructed 
$\mathrm{XJM}$

$17,1 / 2$

20

Table 2.

Population

\section{Methodology}

This study adopts a quantitative approach that would be useful in identifying the suitability of the proposed accounting undergraduate accounting degree program structure.

\subsection{Population and sample distribution}

The private and state educational institutions, the audit firms and listed banking and finance companies which are situated in the Western Province, Colombo District (Colombo 1 - 15 area codes) and who are willing to partake were selected and the questionnaires were circulated only among the selected institutions. The number of selected institutions are presented in Table 2. Academics were categorised as lecturer and above level, Accounting students were categorised as final year accounting students of the reputed institutions, accountants in practices were categorised as qualified accountants who are in public practice and accountants in business are categorised qualified professionals working in the accounting field in the selected organisations.

In order to assess the suitability of the proposed degree program structure, four distinctive stakeholders were identified (Academics, Accounting Students, Accountants in Business and Accountants in Practice). The sample distribution and the response rate is presented in Table 3.

A total of 500 questionnaires were circulated among four stakeholders, and received an overall usable response rate of $27 \%$.

\subsection{Questionnaire development and data analyses}

The questionnaire consists of three sections. The first section inquired the demographic information of the respondents. Second section inquired the dimensions of the current degree program. The final section of the questionnaire inquired on the suitability of the proposed accounting degree program with the identified skills as listed in Appendix. Responses were collected via a five-point Likert scale.

Frequency distribution statistics was applied to examine the demographic characteristics of the respondents and to examine the perception, brand and output of the existing degree program.

Non-parametric Krushkal-Wallis test of variance was applied to examine the difference in the responses of the ranked data. As the data collected via Likert scale, violates the

\begin{tabular}{lccc}
\hline No. of private and public educational institutions & $\begin{array}{c}\text { No. of audit } \\
\text { firms }\end{array}$ & $\begin{array}{c}\text { No. of banking } \\
\text { institutions }\end{array}$ & $\begin{array}{c}\text { No. of } \\
\text { finance institutions }\end{array}$ \\
\hline 32 (Public 28; Private 4) & 37 & 13 & 18 \\
Source: Author constructed & & & \\
\hline
\end{tabular}

\begin{tabular}{lccc}
\hline No. of questionnaires circulated & $\begin{array}{c}\text { No. of responses } \\
\text { received }\end{array}$ & $\begin{array}{c}\text { No. of usable } \\
\text { responses }\end{array}$ & $\begin{array}{c}(\%) \text { of the } \\
\text { usable responses }\end{array}$ \\
\hline 500 & 154 & 136 & 27 \\
Source: Author constructed & & & \\
\hline
\end{tabular}

Table 3.

Sample distribution

Source: Author constructed 
normality assumptions therefore non-parametric tests are applied. The next section provides the statistical results and discussion of the study.

\section{Data analysis and results}

\subsection{Demographic factors}

As per the statistics in Table 4, the highest response rate (54\%) was received from students and the lowest response rate $(9 \%)$ was received from academics. A total of 28 accounting practitioners in business and 23 accountants in public practice had responded to the survey, representing a response rate of $21 \%$ and $17 \%$, respectively. In terms of the highest academic qualification 32 $(23 \%)$ respondents have a post graduate qualification and $14(10 \%)$ respondents do not have an academic qualification. Among the sample $25 \%$ of the respondents had recommended Chartered Institute of Management Accountants (CIMA - UK) as a preferred foreign professional accounting qualification and $70 \%$ of the respondents had selected Institute of Chartered Accountants of Sri Lanka (CASL) as the preferred national professional accounting qualification.

\subsection{Perceptions of the existing state degree program}

As per the statistics in Table 5, the results for $H 1$ is significant at both $5 \%$ and $1 \%$. However, it is pertinent to note that there is a significant group difference. Mostly, there is a significant disagreement among academics and students. This may be owing to the prevailing conception that in order to progress in academic career, it is preferred to have academic degrees that are heavily focused on academic knowledge rather than professional needs of the business world. On the other hand, professionals are under the impression that academic degrees do not provide practical knowledge to cope with the business world. Further, in Sri Lankan academic education progression pillar, students and professionals who are passed finalist or members of a professional accounting bodies can apply for postgraduate studies.

As per the statistics in Table 6, 75\% of the respondents "Agree" and $2.2 \%$ of the respondents "Strongly Agree" to the statement "Existing state accounting degree program is more processed based rather than outcome based" whilst $14.7 \%$ of the respondents had disagreed and $8.1 \%$ of the respondents had provided a neutral response to the statement. Only 4 academics in the sample had agreed with the above statement. Employers

\begin{tabular}{|c|c|c|c|c|c|}
\hline Demographic factors & $\begin{array}{c}\text { Academics } \\
n,(\%)\end{array}$ & $\begin{array}{c}\text { Students } \\
n,(\%)\end{array}$ & $\begin{array}{c}\text { Accountants } \\
\text { in Business } \\
n,(\%)\end{array}$ & $\begin{array}{c}\text { Accountants } \\
\text { in Practice } \\
n,(\%) \\
\end{array}$ & \\
\hline Respondents (n) & $12(9 \%)$ & $73(54 \%)$ & $28(21 \%)$ & $23(17 \%)$ & \\
\hline $\begin{array}{l}\text { Academic qualification } \\
\text { No Academic } \\
\text { Qualification } \\
\text { Certificate } \\
\text { Diploma } \\
\text { Under Graduate Degree } \\
\text { Post Graduate Degree }\end{array}$ & $\begin{array}{l}\text { ademic qualif } \\
\quad- \\
- \\
- \\
- \\
12(9 \%)\end{array}$ & $\begin{array}{c}- \\
- \\
- \\
73(54 \%)\end{array}$ & $\begin{array}{r}2(1 \%) \\
- \\
8(6 \%) \\
18(13 \%)\end{array}$ & $\begin{array}{c}12(9 \%) \\
- \\
- \\
9(7 \%) \\
2(1 \%)\end{array}$ & \\
\hline $\begin{array}{l}\text { Professional Qualification } \\
\text { CMA Sri Lanka } \\
\text { CA Sri Lanka } \\
\text { CIMA UK }\end{array}$ & $\begin{array}{c}\text { Professional } \\
- \\
4(3 \%) \\
8(6 \%)\end{array}$ & $\begin{array}{l}\text { fication) } \\
5(4 \%) \\
56(41 \%) \\
12(9 \%)\end{array}$ & $\begin{array}{r}2(1 \%) \\
12(9 \%) \\
14(10 \%)\end{array}$ & $\begin{array}{c}- \\
23(17 \%) \\
-\end{array}$ & $\begin{array}{r}\text { Table } 4 . \\
\text { Demographic factors }\end{array}$ \\
\hline
\end{tabular}


XJM

$17,1 / 2$

22

\begin{tabular}{|c|c|c|c|}
\hline \multirow{4}{*}{$\begin{array}{l}x \mathrm{JIV1} \\
17,1 / 2\end{array}$} & Respondents & Likert & H1 \\
\hline & \multirow[t]{7}{*}{ Academic } & Strongly Disagree & 0 \\
\hline & & Disagree & $\begin{array}{l}0.0 \% \\
4\end{array}$ \\
\hline & & & $2.9 \%$ \\
\hline \multirow[t]{2}{*}{22} & & Neutral & 5 \\
\hline & & Agree & $\begin{array}{l}. .1 / 0 \\
3\end{array}$ \\
\hline & & & $\begin{array}{l}2.2 \% \\
0\end{array}$ \\
\hline & & & $0.0 \%$ \\
\hline & \multirow[t]{6}{*}{ Students } & Strongly Disagree & 0 \\
\hline & & Disagree & $\begin{array}{l}0.0 \% \\
20 \\
14.7 \%\end{array}$ \\
\hline & & Neutral & $\begin{array}{c}14.1 \% 0 \\
3\end{array}$ \\
\hline & & & $2.2 \%$ \\
\hline & & Agree & $\begin{array}{l}50 \\
36.8 \%\end{array}$ \\
\hline & & Strongly Agree & 0 \\
\hline & \multirow[t]{7}{*}{ Accountants in Business } & Strongly Disagree & $\begin{array}{l}0.0 \% \\
0\end{array}$ \\
\hline & & Disagree & $\begin{array}{l}0.0 \% \\
5\end{array}$ \\
\hline & & & $3.7 \%$ \\
\hline & & Neutral & $\begin{array}{l}0 \\
0.0 \%\end{array}$ \\
\hline & & Agree & 20 \\
\hline & & Stronglv Agree & $14.7 \%$ \\
\hline & & & $2.2 \%$ \\
\hline & \multirow[t]{7}{*}{ Accountants in Practice } & Strongly Disagree & 0 \\
\hline & & Dica ren & $0.0 \%$ \\
\hline & & Disagree & $0.0 \%$ \\
\hline & & Neutral & 0 \\
\hline & & A оreе & $0.0 \%$ \\
\hline & & & $14.7 \%$ \\
\hline & & Strongly Agree & 3 \\
\hline & \multirow[t]{7}{*}{ Total } & Strongly Disagree & $\begin{array}{l}2.2 \% \\
0\end{array}$ \\
\hline & & & $0.0 \%$ \\
\hline & & Disagree & 29 \\
\hline & & Noutral $\mathrm{a}$ & $21.3 \%$ \\
\hline & & Nentrat & $\begin{array}{l}0 \\
5.9 \%\end{array}$ \\
\hline & & Agree & 93 \\
\hline \multirow{4}{*}{$\begin{array}{l}\text { Table } \mathbf{5} \text {. } \\
\text { Hypothesis test } \\
\text { results }\end{array}$} & & Strongly Agree & $\begin{array}{l}0.4 / 0 \\
6\end{array}$ \\
\hline & \multirow{3}{*}{ Significance } & & $4.4 \%$ \\
\hline & & $5 \%$ & Yes \\
\hline & & $1 \%$ & Yes \\
\hline
\end{tabular}




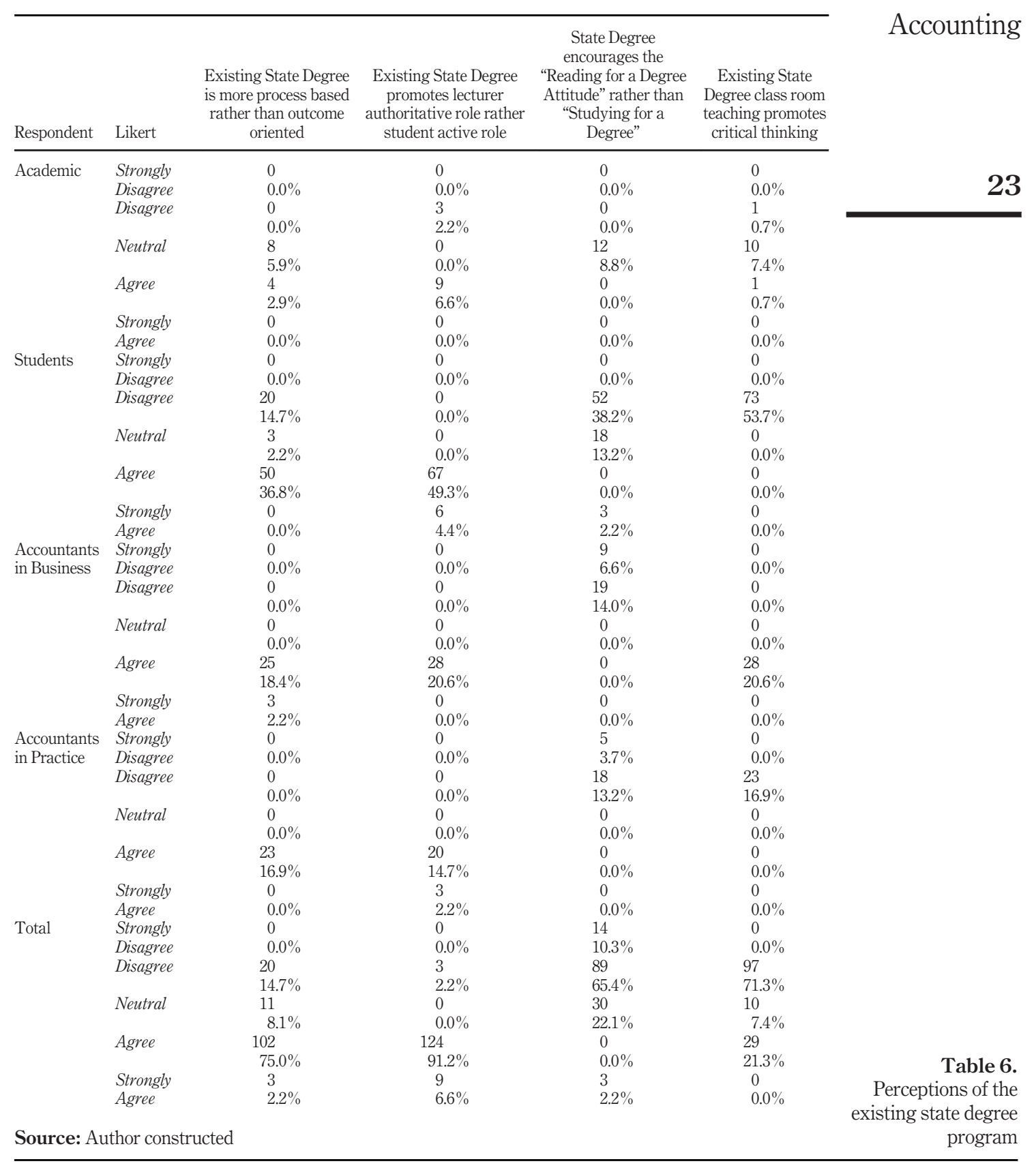


$\mathrm{XJM}$

$17,1 / 2$

(Accountants in Business and in Practice) do not perceive that the state degree program is outcome oriented as this demography in the sample employs the accounting undergraduates and do not perceive that academic degrees produce the required value addition or the output required by the organisations. A total of $97.8 \%$ of the respondents had agreed $(91.2 \%$ agreed and $6.6 \%$ strongly agreed) to the statement "Existing state degree promotes lecturer authoritative role rather than student participative role". Even though there is significant advancement made in technologies relating to teaching in the western civilization, similar advancement has not been achieved or implemented by the state degree programs. Traditional lecturer authoritative role discourages student participation in class room teaching and dampens their creative thinking and creativity. Reading is considered as a complex practice of attaining knowledge. It requires the students to have a good cognition strategy functions to know the heading, structure and summary of the text. It also requires stages of reading skill such as extensive reading (to know the information deeply), skimming (to know the general ideas) and scanning (to know the detail information) (Brich, 2002). However, the existing degree program does not encourage reading for a degree rather encourages memorising study notes attitude. $65.4 \%$ of the respondents had disagreed and $10.3 \%$ of the respondents had strongly disagreed to the statement "State degree encourages reading for a degree attitude rather than studying for a degree". A total of $22.1 \%$ of the respondents had provided a neutral response for above statement as this respondent group may not acknowledge that there is a difference between the terminology "Reading" and "Studying" for a degree. A total of $71.3 \%$ of the respondents had disagreed and $21.3 \%$ of the respondents had agreed to the statement that "Existing state degree class room teaching promotes critical thinking". The disagreement may be due to the belief that the existing state accounting degree program does not completely eradicate critical thinking among accounting students.

\subsection{Brand recognition}

As per the statistics in Table 7, 55.1\% of the respondents and $22.8 \%$ of the respondents had stated that the national recognition for existing state degree program is high and very high respectively. However, $50.7 \%$ of the respondents had stated that the international recognition for state degree programs is moderate, this may be due high competition from international graduates and high demand for professionally qualified students. Further, it is pertinent to note that Sri Lankan universities are well behind the world ranking (Webmetrics, 2020). But 22.8\% of the respondents and $2.9 \%$ of the respondents had stated that the international recognition for existing state degree program is high and very high respectively. $64.7 \%$ of the respondents and $35.3 \%$ of the respondents had stated that the possibility to advance to post graduate studies with state degree program within national institutes is high and very high respectively. As per the Sri Lankan Qualification Framework, students with first class honours degree in any field can progress to Doctor of Philosophy (PhD) (UGC, 2015). $72.0 \%$ of the respondents had stated that the possibility is high for students (46.3\% - High and $25.7 \%$ - Very High) to progress to post graduate studies with state degree programs offered by foreign universities. There is severe competition among international students for international post graduate qualifications. There is unanimous consensus among respondents that state degree program recognition for employability to national organisations (83.8\% - High and $16.2 \%$ - Very High). $50.0 \%$ of the respondents and $9.6 \%$ of the respondents had stated that the international recognition for existing state degree program for employability in foreign organisations is high and very high respectively. The differences in the responses is may be because foreign organisations accept various other international professional qualifications and other international academic qualifications. 


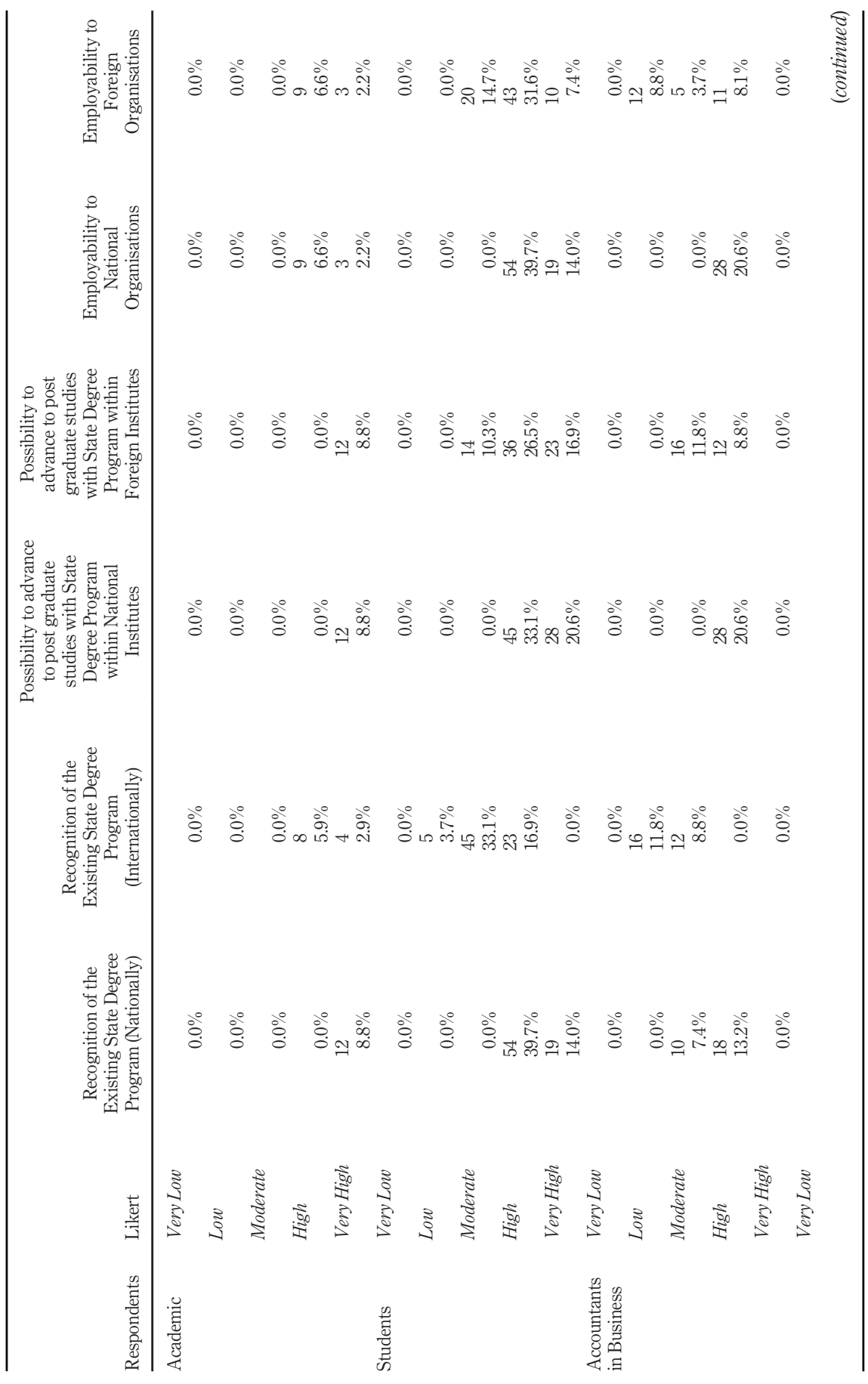

Accounting

25 
XJM
$17,1 / 2$

26

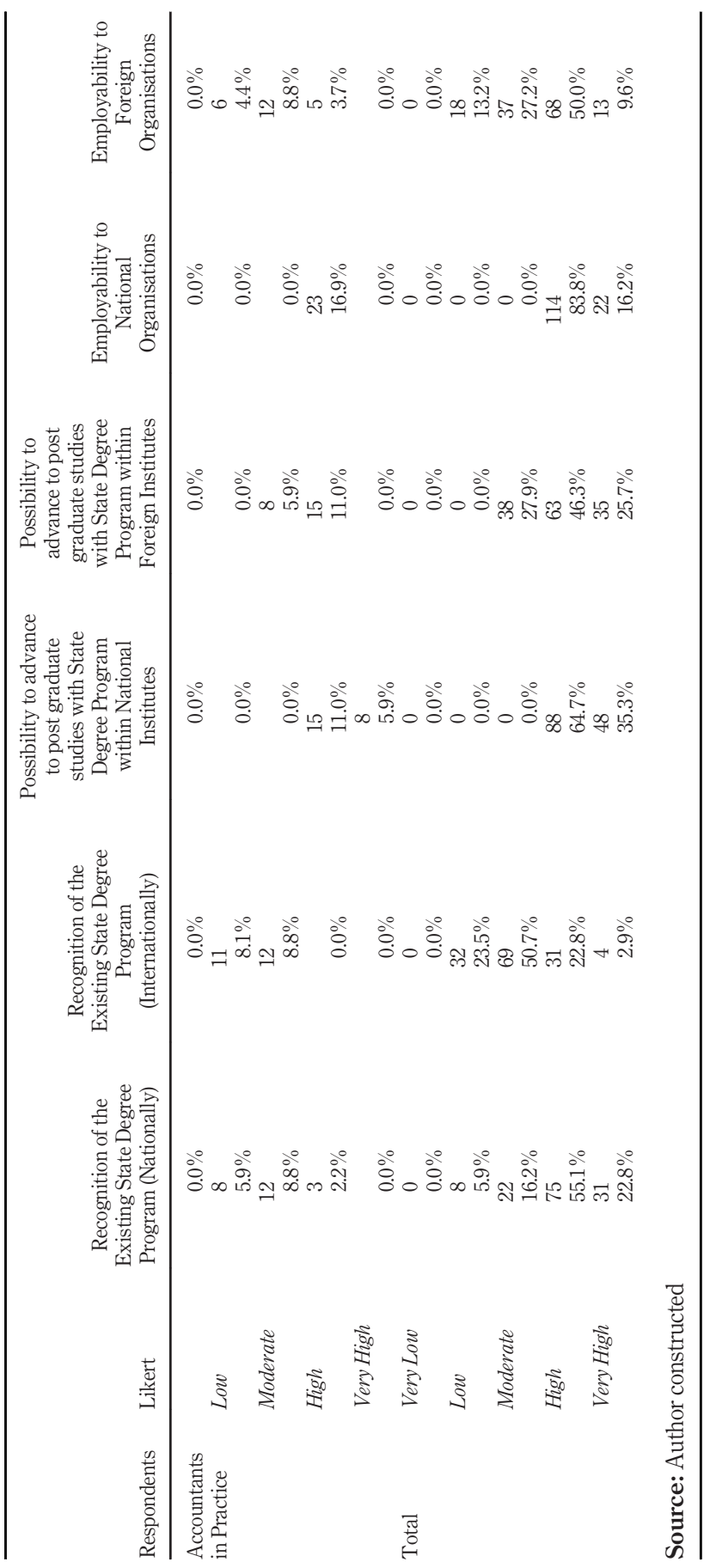


As per the statistics in Table 8, 69.8\% of the respondents had disagreed to the statement

"New graduates are immediately suited practice", and $14.0 \%$ of the respondents had agreed to the statement. This is because academics, students and professional accountants in business may believe that the theoretical knowledge is adequate to enter and encounter the problems in Sri Lanka, further additional skills and competencies can be gained via work experience. A total of $74.2 \%$ of the respondents had agreed that new graduates possess adequate theoretical knowledge in accounting which is gained via the existing state degree program. A total of $52.2 \%$ of the respondents had disagreed to the statement "New graduates possess adequate intellectual skills" and $22.8 \%$ of the respondents had agreed, to a certain extent students do acquire the relevant intellectual skills presented in Appendix while studying in a university. However, the disagreement may be due to that new graduates' intellectual skill level is not to the expected level by the professional practicing accountants in business and public practices. $62.5 \%$ (61.8\% disagreed and $0.7 \%$ strongly disagreed) of the respondents disagreed to the statements new graduates do possess adequate interpersonal and communication, personal and organisational skills. This is because the existing state degree program heavily focuses on building a theoretical foundation and less attention is given to the other skills.

\subsection{Suitability of the identified skills for the proposed accounting degree program}

4.5.1 Intellectual skills. As per the statistics presented in the Table 9, able to deal with complexity, analytical thinking, critical thinking for unstructured problems, evaluation of options and innovative thinking skills are significant at both $5 \%$ and $1 \%$. Problem solving of structured and unstructured questions is only significant at $5 \%$. The four respondents have selected different skills as their priority, Academics have opted mostly for "Research aptitude" skill as it is one of the utmost requirement for their career progression. Students have opted "Problem solving of structured and unstructured questions" as the most important skill, as for students it can be considered as most significant because passing the examination requires solving varies structured and unstructured questions. For accountants in business "Able to deal with complexity" is the most desired skill as accountants in business, work in a very dynamic business environment, therefore to be a successful accountant in business should be able to face and adopt to various changing business circumstances. "Professional judgement" is the most desired skill by accountants in practice as auditors place highest importance in professional judgement in forming the "audit opinion”.

4.5.2 Interpersonal and communication skills. As per the statistics presented in the Table 10, oral communication, presentation skills, reading skills, team work and written communication skills are significant at both $5 \%$ and $1 \%$. Management Consultancy Skills and Negotiation Skills are significant at both 5\%. All the respondents had selected "Written communication" as the most important skill and "Appreciation of cross culture differences" as the least ranked skill.

4.5.3 Personal skills. As per the statistics presented in the Table 11, Time Management, Work Life Balance, Language Proficiency (English), Meeting Deadlines, Punctuality skills are significant at both $5 \%$ and $1 \%$. Continuous learning is only significant at $5 \%$. Students and Academics have opted "Time management" as the most important skill. Accountants in business and practice have ranked "Work life balance" as the most important skill. Work life balance is the utmost problem for working professionals. Even though Sri Lanka depicts a 92\% literacy rate (User, 2020) students have ranked "Language proficiency - English" as 
XJM

$17,1 / 2$

\section{8}

Table 8.

Quality of output (skills)

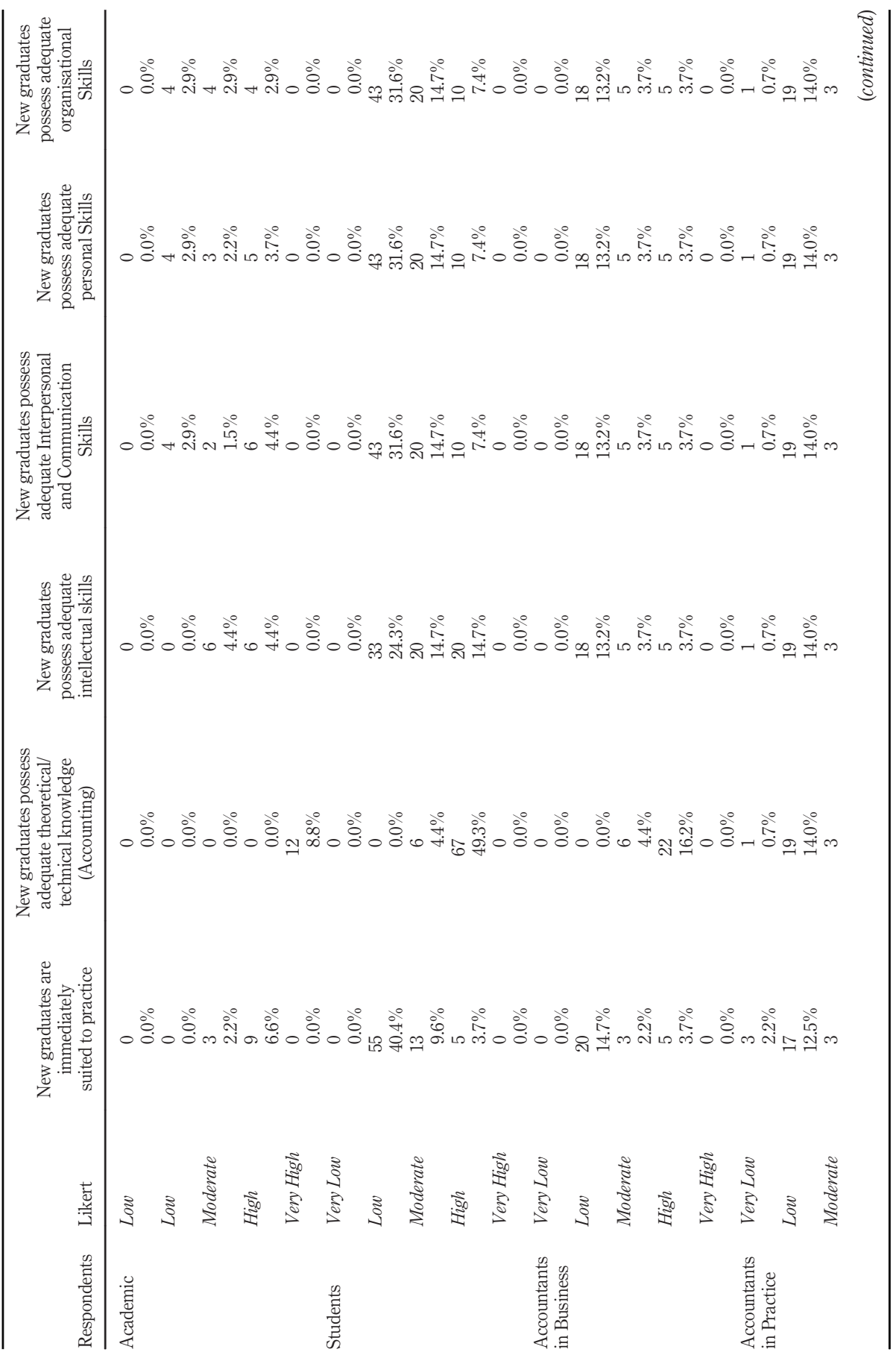




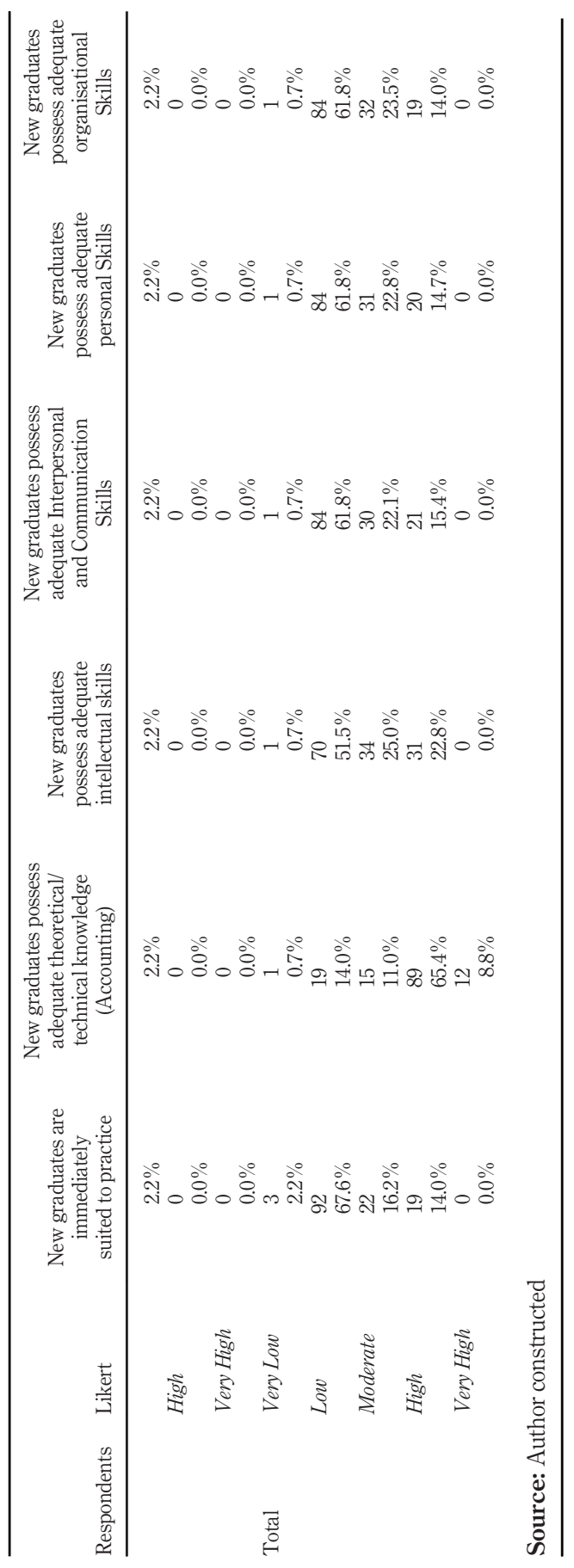

Accounting

29 


\begin{tabular}{|c|c|c|c|c|c|c|c|}
\hline \multirow{3}{*}{$\begin{array}{l}\mathrm{XJM} \\
17,1 / 2\end{array}$} & & & & & & & \\
\hline & \multirow[b]{2}{*}{ Intellectual skills } & \multirow{2}{*}{$\begin{array}{l}\text { Academics } \\
\text { Rank }\end{array}$} & \multirow{2}{*}{$\begin{array}{l}\text { Students } \\
\text { Rank }\end{array}$} & \multirow{2}{*}{$\begin{array}{c}\text { Accountants } \\
\text { in business } \\
\text { Rank }\end{array}$} & \multirow{2}{*}{$\begin{array}{c}\text { Accountants } \\
\text { in practice } \\
\text { Rank }\end{array}$} & \multicolumn{2}{|c|}{ Significantly different } \\
\hline & & & & & & $5 \%$ & $1 \%$ \\
\hline \multirow{4}{*}{30} & IS.1 & 4 & 3 & 1 & 2 & Yes & Yes \\
\hline & IS.2 & 5 & 2 & 3 & 3 & Yes & Yes \\
\hline & IS.3 & 2 & 4 & 2 & 4 & Yes & Yes \\
\hline & IS. 4 & 3 & 6 & 4 & 5 & Yes & Yes \\
\hline \multirow{6}{*}{$\begin{array}{l}\text { Table } 9 . \\
\text { Intellectual skills }\end{array}$} & IS.5 & 7 & 5 & 5 & 7 & Yes & Yes \\
\hline & IS.6 & 6 & 1 & 6 & 6 & Yes & No \\
\hline & IS.7 & 9 & 7 & 7 & 1 & No & No \\
\hline & IS. 8 & 8 & 8 & 8 & 8 & No & No \\
\hline & IS.9 & 1 & 9 & 9 & 9 & No & No \\
\hline & \multicolumn{7}{|c|}{ Source: Author constructed } \\
\hline
\end{tabular}

Interpersonal and

\begin{tabular}{|c|c|c|c|c|c|c|}
\hline \multirow{2}{*}{$\begin{array}{l}\text { Interpersonal and } \\
\text { communication } \\
\text { skills }\end{array}$} & \multirow{2}{*}{$\begin{array}{c}\text { Academics } \\
\text { Rank }\end{array}$} & \multirow{2}{*}{$\begin{array}{c}\text { Students } \\
\text { Rank }\end{array}$} & \multirow{2}{*}{$\begin{array}{c}\text { Accountants } \\
\text { in business } \\
\text { Rank }\end{array}$} & \multirow{2}{*}{$\begin{array}{c}\text { Accountants } \\
\text { in practice } \\
\text { Rank }\end{array}$} & \multicolumn{2}{|c|}{$\begin{array}{c}\text { Significantly } \\
\text { different }\end{array}$} \\
\hline & & & & & $5 \%$ & $1 \%$ \\
\hline ICS.1 & 10 & 10 & 10 & 10 & No & No \\
\hline ICS.2 & 9 & 9 & 9 & 9 & No & No \\
\hline ICS.3 & 7 & 8 & 8 & 8 & No & No \\
\hline ICS.4 & 8 & 7 & 7 & 6 & Yes & No \\
\hline ICS.5 & 6 & 6 & 6 & 7 & Yes & No \\
\hline ICS.6 & 4 & 2 & 2 & 2 & Yes & Yes \\
\hline ICS.7 & 2 & 4 & 4 & 4 & Yes & Yes \\
\hline ICS.8 & 3 & 3 & 3 & 3 & Yes & Yes \\
\hline ICS.9 & 5 & 5 & 5 & 4 & Yes & Yes \\
\hline ICS.10 & 1 & 1 & 1 & 1 & Yes & Yes \\
\hline Source: Author & & & & & & \\
\hline
\end{tabular}

the second most important skill. Even though the official language of Sri Lanka is "Sinhala", "English" is considered as the professional working language.

4.5.4 Organisation skills. As per the statistics presented in the Table 12, taking accountability, taking responsibility, team work and use of appropriate technology skills are both significant at 5\% and 1\%. Self-Reviewing Ability and Decision making skills are significant at $5 \%$. Taking accountability and taking responsibility skills are ranked top two skills by the academics, accountants in practice and business.

4.5.5 Technical skills. As per the statistics presented in the Table 13, Financial Accounting, Corporate Reporting and Financial Analysis, Taxation and Management Accounting skills are both significant at $5 \%$ and $1 \%$. Auditing and Assurance, Financial Strategy and Valuation, Corporate Governance and Ethics and Accounting Information System are significant at $5 \%$. It is evident that accountants in practice have placed an importance on subjects relating auditing whilst accountants in business have placed an importance on accounting and financial reporting related subjects. 


\begin{tabular}{lcccccc}
\hline Personal & Academics & Students & $\begin{array}{c}\text { Accountants } \\
\text { in business } \\
\text { Rank }\end{array}$ & $\begin{array}{c}\text { Rank } \\
\text { skills }\end{array}$ & $\begin{array}{c}\text { Accountants } \\
\text { in practice } \\
\text { Rank }\end{array}$ & \multicolumn{2}{c}{$\begin{array}{c}\text { Significantly } \\
\text { different }\end{array}$} \\
\hline PS.1 & 15 & 16 & 15 & 16 & No & No \\
PS.3 & 6 & 6 & 8 & 10 & Yes & No \\
PS.4 & 16 & 10 & 9 & 11 & No & No \\
PS.5 & 14 & 15 & 16 & 15 & No & No \\
PS.6 & 12 & 11 & 10 & 9 & No & No \\
PS.7 & 10 & 8 & 7 & 8 & No & No \\
PS.8 & 3 & 2 & 3 & 4 & Yes & Yes \\
PS.9 & 5 & 5 & 4 & 5 & Yes & Yes \\
PS.10 & 11 & 12 & 11 & 3 & No & No \\
PS.11 & 7 & 7 & 6 & 7 & No & No \\
PS.12 & 4 & 4 & 5 & 6 & Yes & Yes \\
PS.13 & 8 & 13 & 14 & 12 & No & No \\
PS.14 & 9 & 14 & 12 & 13 & No & No \\
PS.15 & 13 & 9 & 13 & 14 & No & No \\
PS.16 & 1 & 1 & 2 & 2 & Yes & Yes \\
PS.17 & 2 & 3 & 1 & 1 & Yes & Yes
\end{tabular}

Accounting

Source: Author constructed

Table 11.

Personal skills

\begin{tabular}{lcccccc}
\hline $\begin{array}{l}\text { Organisation } \\
\text { skills }\end{array}$ & $\begin{array}{c}\text { Academics } \\
\text { Rank }\end{array}$ & $\begin{array}{c}\text { Students } \\
\text { Rank }\end{array}$ & $\begin{array}{c}\text { Accountants } \\
\text { in business } \\
\text { Rank }\end{array}$ & $\begin{array}{c}\text { Accountants } \\
\text { in practice } \\
\text { Rank }\end{array}$ & \multicolumn{2}{c}{$\begin{array}{c}\text { Significantly } \\
\text { different } \\
5 \%\end{array}$} \\
\hline OS.5 & 8 & 9 & 6 & 8 & No & No \\
OS.4 & 3 & 2 & 5 & 6 & Yes & No \\
OS.8 & 6 & 7 & 9 & 9 & No & No \\
OS.6 & 7 & 6 & 7 & 7 & No & No \\
OS.9 & 9 & 8 & 8 & 3 & Yes & No \\
OS.1 & 2 & 4 & 2 & 2 & Yes & Yes \\
OS.2 & 1 & 1 & 1 & 1 & Yes & Yes \\
OS.3 & 4 & 5 & 4 & 5 & Yes & Yes \\
OS.7 & 5 & 3 & 3 & 4 & Yes & Yes
\end{tabular}

Source: Author constructed

Table 12.

Organisation skills

\subsection{Discussion of the results}

The uniqueness of the proposed accounting degree program is that it is proportionately divided and separately focused on the technical and generic skills. The proposed accounting degree program supports the argument laid by Pazil and Razak (2019), where it is stated that skills that are necessary to excel in the workplace cannot be acquired through classroom teaching alone. The main reason for the poor generic skills compared to technical skills among Sri Lankan accounting undergraduates may be due to the fact that students are fully occupied in pursuing academic qualification simultaneously with professional accounting qualifications. The burden of theory based academic curricula overemphasis on technical skills development deters students' creativity and the opportunity to acquire other generic skills. It is evident that the practical experience element of the existing accounting 


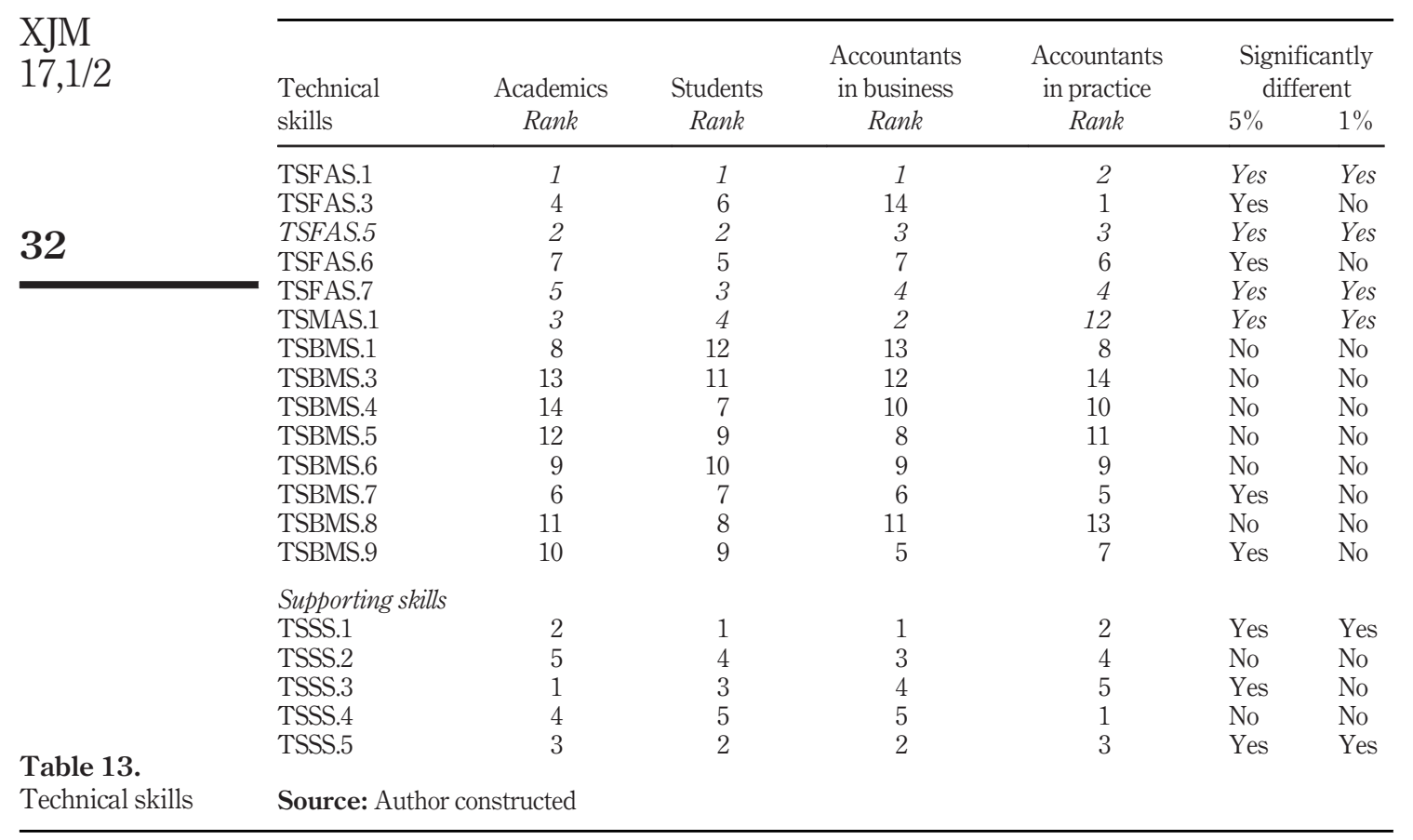

education model is not adequate to meet the employer demands, given the fact that students enter into the university with few generic skills (Abayadeera and Watty, 2016). Sir Ken Robinson stated the universal education system places much more importance on subjects that are demanded by the industry requirements, solely focusing on such requirements will likely to reduce the creativity and other skill development (Do schools kill creativity?, 2017).

Abayadeera and Watty (2016) stated that the absence of linkage between universities and employers may be one of the reasons for the low level of generic skills among accounting undergraduates. Formal relationships between universities and employers will likely to improve the graduates' skill development. This shared approach acknowledges that some generic skills are better developed in the work place. The proposed model will likely to address this concern identified by Abayadeera and Watty's study. When transforming from class room teaching to experiential learning environment lecturers and instructors should ensure that student learning and course objectives are met. Universities incorporating such learning models require consultations and other forms of facilitations from external organisations (For example, National and International Professional Accounting Bodies and Employers) to successfully implement such programmes. Inadequate preparation, poor implementation and improper conduct of the programme can lead to low student satisfaction and in long term it can cause detrimental impact on student recruitments and retentions. Poor communication with partner organisations can lead to incomplete learning cycles.

\section{Conclusion}

The purpose of this paper is to identify the knowledge and practice gap in accounting education and propose an alternative teaching method to align accounting education to meet 
the need of a practical world. This paper would assist accounting instructors and educators to develop and implement experiential and practical accounting module. Universities are expected continuously improve and respond to critical thinking skills. The proposed model would be beneficial for universities in developing countries. Frequency statistics was performed to examine the demographic factors of the respondents. Group differences and ranking statistical tests were performed to identify the preferred generic and technical skills. Under the new proposed program students would be exposed to experiential learning, practical work environment, as well as an opportunity skill development programs. Even though there are discrepancies over the preferences in the skills required by different stakeholders, professional accountants are required by the IES to have an overall acquisition of generic and technical skills.

Modifying the existing undergraduate degree program to the proposed undergraduate degree program is not an easy task. Particularly for developing countries such as Sri Lanka, where there is an enormous amount bureaucratic and red tape procedures to comply. However, the insights of from this study would be beneficial for policymakers and policy implementers to take remedial actions necessary to implement experiential learning.

This study is subject to certain limitations and the findings of this study should be interpreted upon considering such limitations. This study only considers skills based on IES handbook and the technical skills were selected based on the Institute of CASL (ICASL) and Institute of Certified Management Accountants of Sri Lanka syllabuses, and this study does not take into account of other international accounting programs which influence employer preferences. Future researchers can assess the success rate of the new proposed accounting degree program in national or private institutional setting. Further, future research can be extended to incorporate other components that would enhance the accounting degree curricula.

\section{References}

Abayadeera, N. and Watty, K. (2016), "Generic skills in accounting education in a developing country", Asian Review of Accounting, Vol. 24 No. 2, pp. 149-170.

Albrecht, W.S. and Sack, R.J. (2000), "Accounting education: charting the course through a perilous future", Accounting Education Series, American Accounting Association, Sarasota, FL, Vol. 16.

Brich, B.M. (2002), English L2 Reading: Getting to the Bottom, Lawrence, London.

CA Sri Lanka (2020), "CA curriculum”, available at: www.casrilanka.com/casl/index.php?option= com_content\&view=article\&id=65\&Itemid=76\&lang=en (accessed 15 June 2019).

CMA Sri Lanka (2018), CMA Professional Programme Handbook 2018-2022, Institute of Certified Management Accountants of Sri Lanka, Colombo, pp. 1-152.

Cowan, J. (1985), "Effectiveness and efficiency in higher education", Higher Education, Vol. 14 No. 3, pp. 235-239.

Craig, R. and Amernic, J. (2002), "Accountability of accounting educators and the rhythm of the university: resistance strategies for postmodern blues", Accounting Education, Vol. 11 No. 2, pp. 121-171.

Dellaportas, S. (2015), "Reclaiming ‘sense' from 'cents' in accounting education”, Accounting Education, Vol. 24 No. 6, pp. 445-460.

Do schools kill creativity? (2017), "Sir Ken Robinson | ted talks", available at: www.youtube.com/ watch? $v=i G 9 C E 55 w b t Y$ (accessed 18 June 2015).

Ferguson, J., Collison, D., Power, D. and Stevenson, L. (2010), “The views of 'knowledge gatekeepers' about the use and content of accounting textbooks", Accounting Education, Vol. 19 No. 5, pp. $501-525$. 
$\mathrm{XJM}$

$17,1 / 2$

Handbook of International Education Pronouncements (2017), Handbook of International Education Pronouncements, International Federation of Accountants, New York, NY.

Hemp, P. (2019), "Rethinking the MBA", Harvard Business Review, available at: https://hbr.org/2009/ 03/rethinking-the-mba.html (accessed 25 September 2019).

Jackling, B. and De Lange, P. (2009), "Do accounting graduates' skills meet the expectations of employers? A matter of convergence or divergence", Accounting Education, Vol. 18 Nos 4/5, pp. 369-385.

Kavanagh, M. and Drennan, L. (2008), "What skills and attributes does an accounting graduate need? Evidence from student perceptions and employer expectations", Accounting and Finance, Vol. 48 No. 2, pp. 279-300.

Kolb, D. (1984), Experimental Learning: Experience as the Source of Learning and Development, Prentice-Hall, Englewood Cliffs.

Kolb, D. (2015), Experiential Learning, Pearson Education, Upper Saddle River, NJ.

Kolb, A. and Kolb, D. (2005), "Learning styles and learning spaces: enhancing experiential learning in higher education", Academy of Management Learning and Education, Vol. 4 No. 2, pp. 193-212.

Likierman, A. (2004), "Key note speech: ideas and practice: why 'academic' should mean 'irrelevant", Fourth International Conference of the Performance Measurement Association, Performance Measurement Association, Edinburgh.

McCarthy, M. (2010), "Experiential learning theory: from theory to practice", Journal of Business and Economics Research (JBER), Vol. 8 No. 5, pp. 131-139.

Mathews, M. (2001), "The way forward for accounting education? a comment on Albrecht and sack 'a perilous future", Accounting Education, Vol. 10 No. 1, pp. 117-122.

MSG Management Study Guide (2020), "Experiential training methods", available at: www. managementstudyguide.com/experiential-training-methods.html (accessed 15 June 2019).

Palm, C. and Bisman, J. (2010), "Benchmarking introductory accounting curricula: experience from Australia", Accounting Education, Vol. 19 Nos 1/2, pp. 179-201.

Pathways Commission (2012), Vision for the First Academic Exposure to Accounting, American Accounting Association, CA.

Pathways Commission (2015), Pathways Commission: In Pursuit of Accounting Curricula of the Future, American Accounting Association, CA.

Pazil, A.H.M. and Razak, R.C. (2019), "Perspectives of Asian employers on graduates soft skills: a systematic review", Universal Journal of Educational Research, Vol. 7 No. 11, pp. 2397-2405.

PwC (2019), "Data-driven white paper", PwC, available at: www.pwc.com/us/en/careers/universityrelations/data-driven.html (accessed 28 July 2019).

Romney, M.B. and Steinbart, P.J. (2018), Accounting Information Systems, Pearson Education Limited, Harlow.

Saudagaran, S.M. (1996), "The first course in accounting: an innovative approach", Issues in Accounting Education, Vol. 11 No. 1, pp. 83-94.

Senaratne, S. and Cooray, M. (2012), Dominance of professional accounting bodies and dependence of universities: the case of accounting education in Sri Lanka. Dominance of professional accounting bodies and dependence of universities: the case of accounting education in Sri Lanka, Melbourne.

Tucker, B.P. and Schaltegger, S. (2016), "Comparing the research-practice gap in management accounting", Accounting, Auditing \& Accountability Journal, Vol. 29 No. 3, pp. 362-400.

Turner, M. and Baskerville, R. (2013), "The experience of deep learning by accounting students", Accounting Education, Vol. 22 No. 6, pp. 582-604. 
UGC (2015), Sri Lankan Qualification Framework, The World Bank funded Higher Education for Twenty First Century (HETC) Project of the Ministry of Higher Education, Nugegoda, pp. 1-42.

User (2020), "Ministry of higher Education - Overview", available at: www.mohe.gov.lk/index.php/ about-ministry/overview (accessed 15 June 2019).

Webb, J. and Chaffer, C. (2016), "The expectation performance gap in accounting education: a review of generic skills development in UK accounting degrees", Accounting Education, Vol. 25 No. 4, pp. 349-367.

Webmetrics (2020), "University world rankings - Asia - Sri Lanka”, available at: www.webometrics. info/en/Asia/Sri\%20Lanka\%20 (accessed 15 June 2019).

Wells, P. (2018), "How well do our introductory accounting text books reflect current accounting practice?", Journal of Accounting Education, Vol. 42, pp. 40-48.

\section{Further reading}

Tucker, P.B. and Lowe, A.D. (2014), "Practitioners are from Mars; academics are from Venus?", Accounting, Auditing and Accountability Journal, Vol. 27 No. 3, pp. 394-425. 
$\mathrm{XJM}$

$17,1 / 2$

36

Personal Skills

Organizational Skills

\section{Table A1.}

Skills sets to be incorporated into proposed accounting education - Part (A)

\section{Appendix}

Competence Area

Intellectual Skills

Interpersonal and Communication Skills

(A)

Source: Author constructed (Adopted from Handbook of International Education Pronouncements, 2017)
Skills sets to be incorporated into proposed accounting education

IS.1. Able to Deal With Complexity

IS.2. Analytical Thinking

IS.3. Critical Thinking for Unstructured Problems

IS.4. Evaluation of Options

IS.5. Innovative Thinking

IS.6. Problem Solving of Structured and Unstructured Questions

IS.7. Professional Judgment

IS.8. Reasoning

IS.9. Research Aptitude

ICS.1. Appreciation of Cross Cultural Differences

ICS.2. Effective Interview Skills

ICS.3. Listening Skills

ICS.4. Management Consultancy Skills

ICS.5. Negotiation Skills

ICS.6. Oral Communication

ICS.7. Presentation Skills

ICS.8. Reading Skills

ICS.9. Team Work

ICS.10. Written Communication

PS.1. Achievement of Targets

PS.2. Arbitration

PS.3. Continuous Learning

PS.4. Cross Functional Knowledge

PS.5. Entrepreneurship

PS.6. Facing Uncertainty

PS.7. Flexibility

PS.8. Language Proficiency (English)

PS.9. Meeting Deadlines

PS.10. Professional Skepticism

PS.11. Professionalism

PS.12. Punctuality

PS.13. Self-Discipline

PS.14. Self-Management

PS.15. Self-Motivation

PS.16. Time Management

PS.17. Work Life Balance

OS.1. Taking Accountability

OS.2. Taking Responsibility

OS.3. Team Work

OS.4. Decision Making

OS.5. Delegation Skills

OS.6. People Management Skills

OS.7. Use of Appropriate technology

OS.8. Leadership Skills

OS.9. Self-Reviewing Ability 


\section{Competence area Accounting subject stream}

Technical Skills* Financial Accounting Stream
Skills tests to be incorporated into proposed accounting education

TSFAS.1. Financial Accounting Fundamentals TSFAS.2. Advanced Financial Accounting TSFAS.3. Auditing and Assurance Fundamentals TSFAS.4. Advanced Auditing and Assurance TSFAS.5. Corporate Reporting and Financial Analysis

TSFAS.6. Financial Strategy and Valuation TSFAS.7. Taxation Fundamentals TSFAS.8. Advanced Taxation Management Accounting Stream TSMAS.1. Management Accounting Fundamentals TSMAS.2. Advanced Management Accounting TSMAS.3. Strategic Management Accounting Business Management Stream

Supportive Stream

TSBMS.1. Corporate Law Fundamentals TSBMS.2. Advanced Corporate Law

TSBMS.3. Fundamental of Business Operations (Operations Management, People Management, Marketing)

TSBMS.4. Project Management

TSBMS.5. Business Strategy

TSBMS.6. Risk Management

TSBMS.7. Corporate Governance, and Ethics

TSBMS.8. Business Economics

TSBMS.9. Accounting Information System

TSSS.1. Computer Based Accounting

TSSS.2. Financial Mathematics

TSSS.3. Statistics for Accounting Research

TSSS.4. Auditing Software

TSSS.5. Business Analytics

Notes: Technical Skills and Supportive Skills are based on the ICASL and ICMASL syllabuses (CMA Sri Lanka, 2018; CA Sri Lanka, 2020)

Source: Author constructed (CMA Sri Lanka, 2018; CA Sri Lanka, 2020)
Table A2. Skills sets to be incorporated into proposed accounting education - Part (B)

\section{Corresponding author}

Shanmugavel Rajeevan can be contacted at: rajee.srs@gmail.com and shan@solidanalytics.com

For instructions on how to order reprints of this article, please visit our website: 